Volume 1 Nomor 2

Agustus 2021

\title{
PENGARUH PENGGUNAAN INFLUENCER INSTAGRAM TERHADAP CITRA MERK DAN DAMPAKNYA TERHADAP PENINGKATAN PENJUALAN
}

\author{
Yogi Sugiarto Maulana ${ }^{1}$, Dian Hadiani ${ }^{2}$, Sri Wahyuni ${ }^{3}$ \\ 1,2 STISIP Bina Putera Banjar \\ ${ }^{3}$ Mahasiswa STISIP Bina Putera Banjar \\ 4091.sm@gmail.com
}

\begin{abstract}
The problem found is that some of the followers still feel afraid when undergoing facials in beauty clinics, they are worried about being purging, afraid of not matching, or even the skin becomes bad condition. The purpose of this research is to influence Influencers on brand image which has an impact on increasing the sales volume of AURA Dermatology Bandung products. The research method used in this study is Explanatory Research with quantitative approach. This research was conducted at AURA Dermatology Bandung. Data collection using questionnaires in google form distributed to 90 customers. Data analysis techniques using correlation analysis, coefficient of determination and hypothesis testing. Based on the results of the research showed that influencer influence on brand image that has an impact on increasing the sales volume of AURA Dermatology Bandung products by $78.5 \%$.
\end{abstract}

Keywords: Influencer, Instagram, Image, Brand, Sales.

\section{ABSTRAK}

Masalah yang ditemukan adalah sebagian di antara follower masih ada yang merasa masih takut saat menjalani facial di klinik kecantikan, mereka khawatir jadi purging, takut tidak cocok, atau malah kulit jadi jelek kondisinya. Tujuan penelitian ini adalah untuk pengaruh Influencer terhadap Citra merek yang berdampak pada peningkatan volume penjualan produk AURA Dermatology Bandung. Metode penelitian yang digunakan dalam penelitian ini adalah penelitian Eksplanasi (Explanatory Research) dengan pendekatan kuantitatif. Penelitian ini dilaksanakan di AURA Dermatology Bandung. Pengumpulan data menggunakan angket dalam google form yang disebarkan kepada 90 pelanggan. Teknik analisa data menggunakan analisis korelasi, koefisien determinasi dan uji hipotesis. Berdasarkan hasil penelitian menunjukkan bahwa pengaruh Influencer terhadap Citra merek yang berdampak pada peningkatan volume penjualan produk AURA Dermatology Bandung sebesar 78,5\%.

Kata Kunci: Influencer, Instagram, Citra, Merek, Penjualan.

\section{PENDAHULUAN}

Era Industri 4.0 telah membawa perubahan bagi perkembangan strategi pemasaran. Seiring dengan perkembangan Era Industri 4.0 tersebut, termasuk di dalamnya yaitu perkembangan teknologi, perkembangan ekonomi serta budaya, masyarakat semakin sadar akan pentingnya perawatan kecantikan, terlebih lagi iklim di Indonesia ini yang tergolong beriklim tropis dan lebih sering terkena paparan sinar matahari, hal itu akan memberikan dampak yang buruk bagi kesehatan kulit kita. Saat ini perawatan wajah tidak hanya diperuntukkan oleh kaum hawa saja, sudah banyak juga kaum adam yang memiliki kesadaran akan pentingnya perawatan wajah.

Fenomena tersebut yang mendasari munculnya banyak klinik kecantikan yang tersebar dimana-mana yang menawarkan jasa perawatan serta produk untuk memenuhi kebutuhan masyarakat. Klinik-klinik kecantikan yang muncul saat ini, tidak hanya 
menawarkan jasa perawatan yang dilakukan di klinik saja (facial) akan tetapi mereka juga menyediakan produk yang dapat digunakan untuk perawatan di rumah sebagai kelanjutan dari facial agar konsumen mendapatkan hasil yang maksimal sesuai dengan keinginannya. Produk-produk tersebut biasanya berupa sabun muka, sunblock, krim pagi, krim malam, serum dan lain-lain. Persaingan dalam bisnis kecantikan yang semakin tinggi ini mengharuskan perusahaan untuk mengoptimalkan kinerja produk serta pelayanannya agar dapat memuaskan kebutuhan konsumen sehingga hal itu akan berdampak pada meningkatnya keputusan penggunaan jasa.

Aura Dermatology merupakan klinik kecantikan yang menyediakan jasa pelayanan perawatan kulit, wajah dan kecantikan lainnya. Sebagai klinik kecantikan yang hadir diantara klinik-klinik kecantikan lainnya yang sudah hadir sebelumnya, Auro Dermatology memmanfaatkan media sosial dalam strategi marketingnya. Auro Dermatology untuk meningkatkan pemasaran di sosial media, sudah mulai memanfaatkan influencer sebagai strategi marketingnya.

Influencer merupakan seseorang yang memiliki kekuatan untuk mempengaruhi orang lain melakukan keputusan pembelian berdasarkan pengalaman sebelumnya. Influencer digunakan oleh sebuah brand untuk menyampaikan tujuan dari brand ke target konsumen tertentu. Mereka yang menjadi influencer bisa dari kalangan artis atau bahkan selebgram yang menjadi idola dari followers mereka di media sosial. Melihat hal tersebut, perlu dilakukan penelitian untuk menganalisa peran dan strategi yang bisa dilakukan untuk promosi dengan memanfaatkan influencer di media sosial. Media sosial yang dipilih adalah Instagram, dimana Instagram merupakan platform media sosial paling aktif nomor 4 di Indonesia (Hootsuite. 2019) dan Indonesia merupakan negara pengguna Instagram terbanyak se-Asia Pasifik (Hasibuan, Lynda. 2019).
Peran Influencer telah menjadi sebuah strategi pemasaran yang penting bagi sebuah produsen kecantikan yakni untuk dapat mengulas sebuah produk secara baik dan semenarik mungkin, sehingga dapat mempengaruhi pengikutnya. Maka dari itu Instagram dijadikan sebagai alat promosi bagi produsen kecantikan untuk menjualkan produk mereka melalui eksistensi Influencer Instagram. Influencer Instagram ini berfungsi menarik perhatian serta meyakinkan khalayak wanita agar tertarik untuk membeli produk mereka melalui konten review produk kecantikan yang diciptakan oleh Influencer baik yang diunggah ke dalam feed Instagram, Insta Story maupun $I G$ Live di akun pribadi mereka.

Influencer yang berkecimpung di dunia kecantikan sering disebut dengan Beauty Influencer dimana mereka sendiri merupakan seorang yang terkenal di media sosial terutama di beauty community yang khusus berkecimpung di dunia kecantikan. Kehadiran Beauty Influencer tersebut dijadikan salah satu alat untuk mempromosikan oleh sebuah brand kecantikan melalui bentuk penyampaian review yang dibuat semenarik mungkin. Menurut Zukhrufani \& Zakiy (2019) Beauty Influencer dinilai menduduki peran kuat yang berpengaruh bagi para followers yang berjumlah banyak tersebut dikarenakan setiap unggahannya ketika melakukan promosi sebuah produk kecantikan dari sebuah brand.

Berdasarkan pendataan dari beberap komentar pada Instagram Aura Demartology diketahui bahwa : sebagian di antara follower masih ada yang merasa masih takut saat menjalani facial di klinik kecantikan, entah itu takut jadi purging, takut gak cocok, atau malah bukan nya jadi bersih tapi kulit malah jadi jelek kondisi nya. Berdasarkan uraian diatas penulis melakukan penelitian dengan judul "Pengaruh Penggunaan Insfluencer Instagram Terhadap Citra Merk dan Dampaknya Terhadap Peningkatan 
Penjualan pada Klinik Aura Dermatologi Bandung.

\section{KAJIAN PUSTAKA}

Perkembangan teknologi mendorong para pemasar untuk berevolusi dengan kampanye pemasaran di dunia digital. Kemunculan berbagai macam media sosial membut perusahaan tertarik untuk membuat iklan pada media sosial. Perusahaan dapat beriklan melalui saluran resmi atau berhubungan langsung dengan pemilik platfrom . Namun ada fenomena lain yang kini muncul adalah beriklan di media sosial melalui influencer.

Influencer adalah orang-orang yang mempunyai followers (pengikut) atau audience yang cukup banyak di media sosial dan mereka punya pengaruh yang kuat terhadap followers mereka, seperti artis, selebgram, blogger, youtuber dan lain sebagainya. Mereka disukai dan dipercaya oleh followers dan audience sehingga apa yang mereka pakai,sampaikan atau lakukan, dapat menginspirasi dan mempengaruhi para followers, termasuk untuk mencoba dan membeli sebuah produk yang mereka gunakan.

Bentuk dari Pemasaran influencer dapat berupa pos blog, video, atau gambar di saluran media sosial influencer, yang berarti kerjasama konten, dan dapat menjadi konten untuk kampanye pemasaran perusahaan. Influencer marketing adalah strategi pemasaran yang menggunakan influencer atau orang yang berpengaruh di social media. Influencer marketing merupakan cara promosi yang efektif para era sekarang karena konsumen pada era sekarang sudah kurang suka terhadap iklan tradisional. Namun perhatian mereka sehari-hari berada pada sosial media dan mereka suka melihat konten yang menarik dari orang-orang atau influencer yang mereka follow atau ikuti di sosial media.

Hasil penelitian Dimeila (2019) menyebutkan bahwa semakin tinggi visibility, credibility, attraction dan power terhadap selebriti endorser awkarin maka tambah tinggi pula pengaruh pada minat beli followerss mengenai produk endorse tersebut.

Brand Image atau Citra merek merupakan serangkaian asosiasi (persepsi) yang ada dalam benak konsumen terhadap suatu merek, biasanya terorganisasi menjadi suatu makna. Hubungan terhadap suatu merek akan semakin kuat jika didasarkan pada pengalaman dan mendapat banyak informasi. Citra atau asosiasi merepresentasikan persepsi yang bisa merefleksikan kenyataan yang objektif ataupun tidak. Citra yang terbentuk dari asosiasi (presepsi) inilah yang mendasari keputusan membeli bahkan loyalitas merek (brand loyalty) dari konsumen.

Nurcahya (2015) bahwa brand image berpengaruh terhadap minat beli. Promosi merupakan salah satu aspek yang penting dalam manajemen pemasaran dan sering dikatakan sebagai proses berlanjut. Dengan promosi menyebabkan orang yang sebelumnya tidak tertarik untuk membeli suatu produk akan menjadi tertarik dan mencoba produk sehingga konsumen melakukan pembelian. Salah satu strategi promosi yang sedang ramai dilakukan oleh perusahaan kosmetik adalah promosi melalui seorang insfluencer. Insfluencer dibayar oleh perusahaan untuk dapat meningkatkan penjualan produk yang mereka pasarkan. Penggunaan insfluencer diharapkan dapat memberikan citra positif terhadap suatu produk dan merek yang pada akhirnya diharapkan dapat meningkatkan volume penjualan dari sebuah perusahaan.

\section{METODE PENELITIAN}

Jenis penelitian yang digunakan dalam penelitian ini adalah penelitian survei yang bersifat kuantitatif berdasarkan karakteristik masalah penelitian. Populasi dalam penelitian ini adalah keseluruhan konsumen Aura Dermatology, yaitu sebanyak 940 Orang (terhitung dari bulan Februari 2020 sampai dengan bulan Mei 2021). Teknik pengambilan sampel menggunakan rumus 
dari Slovin sebanyak 90 responden. Pengumpulan data dengan menggunakan daftar pertanyaan yang disediakan untuk menjawab pertanyaan secara tertulis oleh responden. Kuisioner berisi pertanyaan, setiap pertanyaan dibuka peluang kemungkinan lima jawaban. Dari lima jawaban tersebut, responden diharapkan memilih satu jawaban yang dianggap paling sesuai dengan dirinya. Masing-masing jawaban mempunyai nilai skor, dimana 1 sangat tidak setuju sampai dengan 5 sangat setuju. Analisis data dilakukan dengan path analisis.

\section{HASIL DAN PEMBAHASAN}

Pengaruh Influencer terhadap Citra merek yang berdampak pada peningkatan volume penjualan produk AURA Dermatology Bandung, maka diperlukan data yang diperoleh dari frekuensi jawaban pegawai. Uji statistik dilakukan dengan uji statistik parametrik yang mensyaratkan jenis jenis data (skala pengukuran data) minimal berjenis interval, maka data berskala ordinal ditransformasikan ke dalam bentuk skala interval dengan menggunakan successive interval method seperti tercantum dalam lampiran.

Hasil perhitungan SPSS diperoleh sebagai berikut :

\begin{tabular}{lcccc}
\hline \multicolumn{4}{c}{ Model Summary } \\
\hline $\begin{array}{l}\text { Mo } \\
\text { del }\end{array}$ & $\mathrm{R}$ & $\mathrm{R}$ & Adjusted & Std. Error of \\
\hline 1 & $.886^{\mathrm{a}}$ & .785 & .782 & 5.495 \\
\hline \multicolumn{4}{l}{$\begin{array}{l}\text { a. Predictors: (Constant), Citra Merek (Y1), } \\
\text { Influencer }(\mathrm{X})\end{array}$} \\
\hline
\end{tabular}

Berdasarkan hasil diatas nilai $\mathrm{R}=$ 0,886 artinya Influencer dan Citra merek memniliki hubungan sangat kuat dengan volume penjualan produk AURA Dermatology Bandung. Untuk mengetahui seberapa besar pengaruh Influencer terhadap Citra merek yang berdampak pada peningkatan volume penjualan produk AURA Dermatology Bandung, digunakan struktur path analisys atau analisis jalur.
Secara lengkap hubungan kausalitas antara variabel $\mathrm{X}$ dan $\mathrm{Y} 1$ serta $\mathrm{Y} 2$ dapat digambarkan sebagai berikut:

\section{Coefficients $^{a}$}

\begin{tabular}{|c|c|c|c|c|c|}
\hline \multirow[b]{2}{*}{ Model } & \multicolumn{2}{|c|}{$\begin{array}{l}\text { Unstandardized } \\
\text { Coefficients }\end{array}$} & \multirow{2}{*}{$\begin{array}{c}\begin{array}{c}\text { Standardized } \\
\text { Coefficients }\end{array} \\
\text { Beta }\end{array}$} & \multirow[t]{2}{*}{$t$} & \multirow[t]{2}{*}{ Sig. } \\
\hline & B & $\begin{array}{l}\text { Std. } \\
\text { Error }\end{array}$ & & & \\
\hline 1 (Constant) & 6.968 & 3.437 & & 2.027 & .045 \\
\hline $\begin{array}{l}\text { Influencer } \\
(X)\end{array}$ & .380 & .064 & .488 & 5.927 & .000 \\
\hline $\begin{array}{l}\text { Citra Merek } \\
(\mathrm{Y} 1)\end{array}$ & .575 & .109 & .433 & 5.257 & .000 \\
\hline
\end{tabular}

a. Dependent Variable:

Penjualan (Y2)

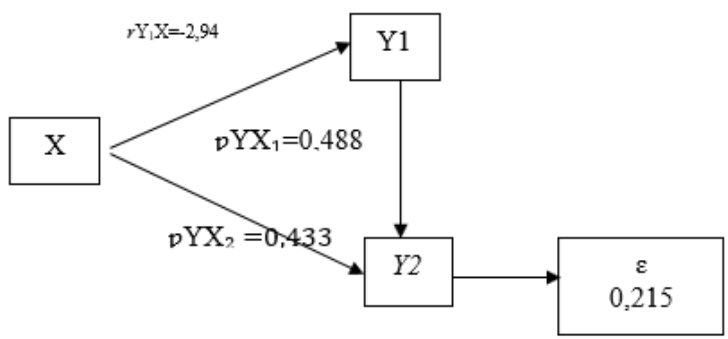

Dari gambar di atas, dapat diketahui nilai koefisien jalur antara variabel independen dan dependen. Nilai koefisien jalur variabel influencer dengan penjualan $\left(\rho Y_{1}\right)$ sebesar 0,488 . Nilai koefisien jalur citra merek ( $\mathrm{Y} 1)$ dengan penjualan $\left(\rho \mathrm{YX}_{2}\right)$ sebesar 0,433 serta epsilon sebesar 0,215. Dari nilai koefisien jalur tersebut secara rinciannya dapat diuraikan sebagai berikut.

\begin{tabular}{|c|c|}
\hline Keterangan & Nilai \\
\hline $\begin{array}{l}\text { Pengaruh } \mathrm{X} \text { terhadap } \\
\text { langsung } \\
\text { lang }\end{array}$ & 0,238 \\
\hline $\begin{array}{l}\text { Pengaruh } \mathrm{X} \text { terhadap } \mathrm{Y} 2 \text { melalui } \mathrm{Y} 1 \\
\text { py }_{1 . \mathrm{X} 1 \mathrm{X} 2} \text {. } \mathrm{py}_{2}\end{array}$ & 0,180 \\
\hline Pengaruh Total X terhadap Y2 & $\mathbf{0 , 4 1 8}$ \\
\hline $\begin{array}{l}\text { Pengaruh } \mathrm{X} \text { terhadap } \mathrm{Y} 2 \text { secara } \\
\text { langsung }\left(\mathrm{pyx}_{2}\right)^{2}\end{array}$ & 0,187 \\
\hline $\begin{array}{l}\text { Pengaruh } \mathrm{X} \text { terhadap Y1 melalui } \mathrm{X} \\
\text { pyx }_{1 . \mathrm{X} 1 \mathrm{X} 2} \text { pyx }_{2}\end{array}$ & 0,180 \\
\hline Pengaruh Total X terhadap Y2 & 0,367 \\
\hline $\begin{array}{l}\text { Pengaruh } X \text {, Y1 secara bersama- } \\
\text { sama terhadap Y2 }\end{array}$ & $\mathbf{0 , 7 8 5}$ \\
\hline Pengaruh Variabel lain & 0,215 \\
\hline
\end{tabular}


Berdasarkan hasil penelitian menunjukkan bahwa terdapat pengaruh Influencer terhadap Citra merek yang berdampak pada peningkatan volume penjualan produk AURA Dermatology Bandung sebesar 78,5\%. Hal ini membuktikan bahwa salah satu faktor yang mendasari keberhasilan penjualan melalui media sosial adalah dengan menggunakan influencer instagram secara definisi influencer marketing adalah sebuah metode dengan menunjuk orang atau figur yang dianggap memiliki pengaruh diantara masyarakat atau segmen target konsumen yang akan dituju dan dirasa dapat menjadi sasaran promosi dari merek tersebut. Penggunaan metode ini akan membuat sang influencer memerankan sebagai pembeli atau pengguna suatu merek yang mampu merepresentasikan tentang halhal positif yang dimiliki merek sehingga dapat meningkatkan tingkat penjualan dari merek produk tersebut. berdasarkan data dan definisi yang ada ini maka peneliti ingin mengetahui peran dari influncer ini sebagai salah satu strategi pemasaran digital di era modern.

Hasil penelitian ini sejalan dengan Hariayanti (2020) bahwa orang influencer dalam memberikan informasi terhadap sebuah produk sehingga tujuan akhir yang ingin dicapai adalah dapat secara signifikan meningkatkan penjualan dan menampilkan citra merek perusahaan yang baik kepada konsumen. Pemanfaatan media sosial tidak hanya dipandang sebagai sarana untuk aktualisasi diri namun dapat berkembang kearah dunia bisnis salah satunya adalah media sosial dapat menjadi sarana pemasaran dan juga dapat dimanfaatkan sebagai sarana untuk mendapatkan review atau informasi mengenai sebuah produk barang atau jasa yang akan atau sedang dipasarkan sehingga dapat menarik minat atau respon dari pelanggan dalam memutuskan untuk melakukan transaksi pembelian.

Influencer Marketing dipandang sebagai salah satu strategi terbaik untuk mendatangkan calon konsumen pada saat melakukan pemasaran menggunakan media sosial dengan memanfaatkan massa yang dimiliki oleh seorang influencer, seorang influncer dapat menciptakan citra merek produk yang lebih baik dan dengan biaya yang lebih murah dibandingkan menggunakan brand endorser artis atau figur publik yang sudah berada kalangan artis papan atas. Seorang influencer secara umum biasanya dipilih berdasarkan kemampuan, keahlian, tingkat popularitas, maupun reputasi yang dimilikinya. Dengan menggunakan metode ini sebuah perusahaan atau merek tertentu diharapkan akan lebih loyal kepada sang influencer yaitu dengan membangun hubungan yang lebih dalam dan tidak hanya sekedar sebatas menjelaskan tentang produk itu saja namun lebih kepada informasi juga fasilitas khusus yang didapatkan terhadap produk baru serta proses dibelakang layar dari merek yang akan dipromosikan. Hal yang perlu diperhatikan saat memilih influencer tentu kembali kepada konsep Segmentasi, sasaran (targetting) dan penempatan (positioning) dari target konsumen yang diinginkan karena hal ini akan berpengaruh terhadap jumlah pengikut dan tingkat keterlibatan platform yang akan digunakan, platform yang dimaksud adalah terkadang seorang influencer dapat menciptakan komunitaskomunitas yang dapat memberikan kesan terhadap produk yang akan dipasarkan, pada beberapa kasus terkadang influencer dengan jumlah pengikut yang kecil namun memiliki keterlibatan yang tinggi dapat lebih efektif dalam mempengaruhi tingkat penjualan produk kepada konsumen.

Selain influencer, citra merek juga berpengaruh terhadap penjualan, Sebuah brand (merek) membutuhkan image (citra) untuk mengkomunikasikan kepada khalayak dalam hal ini pasar sasarannya tentang nilainilai yang terkandung didalamnya (Sulaeman \& Kusnandar, 2020). Bagi perusahaan citra berarti persepsi masyarakat terhadap jati diri perusahaan. Persepsi ini didasarkan pada apa yang masyarakat 
ketahui atau kira tentang perusahaan yang bersangkutan. Oleh karena itulah perusahaan yang memiliki bidang usaha yang sama belum tentu memiliki citra yang sama pula dihadapan orang atau konsumen. Citra merek menjadi salah satu pegangan bagi konsumen dalam mengambil keputusan penting.

Hasil penelitian ini sejalan dengan Nurmiyati (2019) bahwa citra merek berpengaru terhadap penjualan. Dampak dari citra merek yang tinggi dari pelanggan, produk yang berkualitas dari Aura dan nilai yang dirasakan pelanggan akan semakin meningkatkan persepsi yang positif dari pelanggan. Schifmann dan Kanuk (2010) menyebutkan bahwa persepsi adalah cara orang memandang dunia ini. Dengan demikian persepsi seseorang akan berbeda dari yang lain. Cara memandang dunia sudah pasti dipengaruhi oleh sesuatu dari dalam dan dari luar seseorang. Stimulus adalah input bagi proses baik internal maupun eksternal. Stimulus adalah input apapun yang masuk kedalam indera. Sumber stimulus produk, packaging, nama merek, iklan, dan promosi

\section{SIMPULAN}

Influencer instagram AURA Dermatology Bandung termasuk kategori sangat baik. Citra merek AURA Dermatology Bandung termasuk baik. Volume penjualan produk AURA Dermatology Bandung termasuk baik Pengaruh Influencer instagram terhadap citra merk dari AURA Dermatology Bandung sebesar 23,8\%. Pengaruh Influencer instagram terhadap volume penjualan pada AURA Dermatology Bandung sebesar $36,7 \%$. Pengaruh citra merek terhadap volume penjualan pada AURA Dermatology Bandung 18,7\%. Pengaruh Influencer terhadap Citra merek yang berdampak pada peningkatan volume penjualan produk AURA Dermatology Bandung sebesar $78,5 \%$.

\section{REFERENSI}

Amstrong, Kotler (2015), marketing an introducing prentice hall twelfth edition, England : pearson education, Inc

Arifin, Anwar. 2003. Ilmu komunikasi: suatu pengantar ringkas. Jakarta. PT. Rajagrafindo persada.

Atmoko dwi, Bambang. 2012. Instagram handbook tips fotografi ponsel. Jakarta:media kita.

Baharuddin dan Esa Nur Wahyuni, 2007. Teori belajar dan pembelajaran, Jogjakarta: ArRuzz Media.

Fandy Tjiptono., Gregorius Chandra., dan Dedi Adriana., 2008, Pemasaran Strategik, Yogyakarta : CV. Andi Offset.

Fandy Tjiptono dan Gregorius Chandra. 2012. Pemasaran Strategik. edisi 2 Yogyakarta: CV. Andi Offset

Gozhali, Imam 2010. "Aplikasi Analisis Multivariate dengan Program SPSS". Semarang: UNDIP.

Kotler, Philiph (alih bahasa Ancella Anitawati Hermawan SE), Manajemen Pemasaran Analysis, Perencanaan, Implementasi dan Pengendalian, Jakarta: Salemba Empat, 2000

Nasrulloh, Rulli, 2016. Media Sosial: Perspektif Komunikasi, Budaya, dan Sosioteknologi, Bandung: Simbiosa Rekatama Media

Yanuar Widi Prabowo, Suharyono \& Sunarti, Pengaruh Celebrity Endorser Terhadap Minat Beli, Jurnal Administrasi Bisnis (JAB) Vol. 14 No. 2 September 2014

Sulaeman, M., \& Kusnandar, H. F. (2020). Integrated Marketing Communication Model in Shaping Brand Equity and Business Performance in the Creative Industries of Embroidery Sector. Budapest International Research and Critics Institute (BIRCI-Journal): Humanities and Social Sciences, 3(4), 3798-3805.

https://doi.org/10.33258/birci.v3i4.1444

Sabrina Dimeila, Farid: Pengaruh Selebriti Endorser Instagram Terhadap Minat Beli Followers, Prologia EISSN 2598777 Vol. 3, No. 1, Juli 2019

Ni Made Rahayu Wulandari, I Ketut Nurcahya, Pengaruh Celebrity Endorser, Brand Image, Brand Trust 
Terhadap Keputusan Pembelian Clear Shampoo di Kota Denpasar, E-Jurnal Manajemen Unud, Vol. 4, No. 11, 2015

Gayatri Hutami Putri \& Bhina Patria, Pengaruh Endorsement Selebriti Instagram terhadap Minat Beli Remaja Putri, Gadjah Mada Journal of Professional Psychology (Gamajpp) Volume 4, No. 1, 2018

Shiya Azi Sugiharto dan Maulana Rezi Ramadhana, S.Psi., M.Psi, Pengaruh Kredibilitas Influencer Terhadap Sikap Pada Merek, Jurnal Ilmu Politik dan Komunikasi Volume VIII No. 2 Desember 2018 